\title{
A Branched Signaling Pathway for Nerve Growth Factor Is Revealed By Src-, Ras-, and Raf-Mediated Gene Inductions
}

\author{
GABRIELLA D'ARCANGELO AND SIMON HALEGOUA* \\ Department of Neurobiology and Behavior, State University of New York \\ at Stony Brook, Stony Brook, New York 11794-5230
}

Received 9 October 1992/Returned for modification 1 December 1992/Accepted 22 February 1993

\begin{abstract}
A myriad of gene induction events underlie nerve growth factor (NGF)-induced differentiation of PC12 cells. To dissect the signal transduction pathways which lead to NGF actions, we have assessed the relative roles of NGF receptor, Src, Ras, and Raf activities in mediating specific gene inductions. We have used the PC12 cell line as well as sublines which inducibly express activated forms of either Src, Ras, or Raf or a dominant inhibitory form of Ras ( $\mathrm{p}^{\mathrm{N} 17}$ Ras) to study the expression of multiple NGF-inducible mRNAs. The NGF induction of NGFI-A, transin, and VGF mRNAs was mimicked by activated forms of Src, Ras, or Raf and was blocked by p21 ${ }^{\mathrm{N17}}$ Ras. The NGF induction of SCG10 mRNA was mimicked only by activated Src and Ras and was blocked by $\mathrm{p}^{21} 1^{\mathrm{N17}}$ Ras, while the induction of Thy-1 mRNA was mimicked only by activated Src and was not blocked by $\mathrm{p}^{21}{ }^{\mathrm{N17}}$ Ras. The NGF induction of mRNAs for two sodium channel types was neither mimicked by any activated oncoprotein nor blocked by $\mathrm{p}^{21}{ }^{\mathrm{N17}}$ Ras. From these and previous results, we suggest a model in which a linear order of NGF receptor, Src, Ras, and Raf activities is used by NGF to elicit gene inductions. These signaling components define branchpoints in the pathway to specific gene induction events, providing a mechanism for generating a host of diverse NGF actions.
\end{abstract}

Nerve growth factor (NGF) is required for the survival and development of multiple neuronal populations in both the central and peripheral nervous systems (32). NGF also has profound influences on the phenotypic characteristics of both embryonic and adult neurons in vivo and in vitro (33, $46,54,60)$. The rat pheochromocytoma cell line PC12 responds to NGF treatment with the elaboration of a sympathetic neuron-like phenotype, including the extension of neuritic processes, cessation of cell division, the acquisition of a sodium-based action potential mechanism, and the expression of genes encoding neuronal cell-specific proteins (reviewed in reference 19). This cell line has proven to be a useful model system for studying the molecular basis of both short- and long-term NGF actions, elicited from the binding of NGF to its receptor (16).

NGF treatment of PC12 cells activates the intrinsic tyrosine kinase activity of the proto-oncogene product Trk, an essential component of the high-affinity NGF receptor (21, 25,28 ), resulting in the tyrosine phosphorylation of multiple proteins both directly and indirectly $(27,35,50,55-57,59)$. NGF action subsequently involves a host of serine/threonine kinase activities which result in both rapid and long-term effects involving also transcriptional activation of multiple genes (reviewed in reference 19). The intermediary biochemical events that link NGF receptor activation to neuronal phenotypic changes are beginning to be elucidated. At least three additional proto-oncogene products, the tyrosine kinase Src, the GTP-binding protein Ras, and the serine/ threonine kinase Raf, appear to underlie growth factor signal transduction leading to neurite outgrowth. For example, the expression of activated, oncogenic forms of Src, Ras, or Raf in PC12 cells is sufficient to reversibly induce neurite outgrowth through mechanisms which overlap with those used by $\operatorname{NGF}(1,2,42,58$; see also references $17,45,52$, and 56$)$. Antibody microinjection studies and the expression of dom-

\footnotetext{
${ }^{*}$ Corresponding author
}

inant negative mutant proteins in $\mathrm{PC} 12$ cells further demonstrate that the normal cellular counterparts of Src and Ras oncoproteins mediate NGF-induced neurite outgrowth (18, $30,53)$. These approaches, combined with oncogene expression in PC12 cells, demonstrate that Src and Ras act in sequence to mediate neurite growth, with Src acting first (30). NGF causes the hyperphosphorylation of two Raf protein kinases, Raf- 1 and B-Raf $(43,59)$, and activation of B-Raf (43). Raf-1 hyperphosphorylation was mimicked by expression of the Ras oncoprotein and was blocked by the expression of a dominant inhibitory form of Ras in PC12 cells (59), suggesting that a Raf kinase acts downstream of Ras in the NGF signal transduction cascade. A similar sequence of Src, Ras, and Raf activities has been implicated in the signal transduction of mitogenic stimuli $(29,49)$.

In the studies cited above, neurite outgrowth was a primary determinant used to assess the role of proto-oncoproteins in NGF signal transduction. In this study, we examined the role played by Trk, Src, Ras, and Raf activities in inducing the expression of a variety of genes activated at different times after NGF treatment. Using PC12 sublines expressing activated, oncogenic forms of Src, Ras, or Raf or expressing a dominant inhibitory form of Ras, we can now identify several classes of gene inductions that indicate branchpoints in the NGF signal transduction pathway to gene expression. From these data, we derive a model which suggests parallel processing from each of the proto-oncogene components.

\section{MATERIALS AND METHODS}

Cell culture. PC12 (15) and PC12-derived transfectant lines were grown on tissue culture dishes in Dulbecco's modified Eagle's medium (GIBCO) supplemented with $10 \%$ donor horse serum (JRH Biosciences) and 5\% fetal calf serum (JRH Biosciences) in an atmosphere of $10 \% \mathrm{CO}_{2}$. All cell lines except ts:v-src3 were maintained at $37^{\circ} \mathrm{C}$. The ts:v-src3 line was maintained at the partially permissive temperature 
of $39.5^{\circ} \mathrm{C}$ and shifted to the nonpermissive temperature of $41^{\circ} \mathrm{C} 1$ day prior to the shift to the permissive temperature of $35^{\circ} \mathrm{C}$ (see below). NGF, purified from mouse submaxillary glands (40), was added to the culture medium at final concentrations of 50 to $100 \mathrm{ng} / \mathrm{ml}$. Dexamethasone (Sigma) was dissolved in dimethyl sulfoxide and diluted to 0.5 to 1 $\mu \mathrm{M}$ so that the final content of dimethyl sulfoxide in the culture medium did not exceed $0.1 \%$. [ $\alpha{ }^{32}$ P]UTP (800 $\mathrm{mCi} / \mathrm{mmol}$ ) was obtained from NEN.

Generation of plasmids and $\mathrm{PC12}$ sublines. The isolation and characterization of the ts:v-src3 and IC4-raf cell lines are described elsewhere $(56,58)$. Oncogenic Src protein (temperature-sensitive Src mutant NY72-4) in ts:v-src3 cells was activated by shifting the cells from the nonpermissive temperature of $41^{\circ} \mathrm{C}$ to the permissive temperature of $35^{\circ} \mathrm{C}$ by replacing the medium and transferring the cells to a $35^{\circ} \mathrm{C}$ incubator. Expression of oncogenic Raf-1 in IC4-raf cells was induced from a transfected gene containing Raf-1 cDNA placed under the control of the mouse mammary tumor virus (MMTV) promoter by addition of $0.5 \mu \mathrm{M}$ dexamethasone to the culture medium.

GSras1 (30) and GSras2 cell lines were derived from PC12 cells following cotransfection with plasmids pMJC25 (a gift from M. Corbley and T. Roberts) and pRSV-neo (14). Plasmid pMJC25 encodes the oncogenic variant of Ras, p21 ${ }^{\mathrm{L} 61}(10)$, under the control of the dexamethasone-inducible MMTV promoter. The transfection was carried out by electroporation, using a Gene Pulser (Bio-Rad). Approximately $4 \times 10^{6}$ cells were electroporated in $0.4 \mathrm{ml}$ of Dulbecco's modified Eagle's medium containing $18 \mu \mathrm{g}$ of pMJC25 and $2 \mu \mathrm{g}$ of pRSV-neo, using settings of $300 \mathrm{~V}$ and $500 \mu \mathrm{F}$. Two days after transfection, cells were incubated in selective medium containing $800 \mu \mathrm{g}$ of geneticin (GIBCO) per ml. After approximately 3 weeks, neomycin-resistant clones were isolated and then screened for dexamethasoneinduced neurite outgrowth. Two such clones, GSras1 and GSras2, were chosen and further characterized by Northern (RNA) blot analysis (see Results).

GSrasDN6 (55) and GSrasDN13 (30) were isolated after cotransfection of PC12 cells with plasmids pMMrasDN and pRSV-neo (14). Plasmid pMMrasDN encodes the dominant negative form of Ras, p21 ${ }^{\mathrm{N} 17}$ Ras (13), under the control of the MMTV promoter. To create this plasmid, the BglIIBamHI fragment from pXCR Asn17 (13) encoding p21 ${ }^{\mathrm{N} 17}$ was cloned into the BamHI site of pMM42K (58) from which the raf insert had been excised. Transfection was carried out as described above, using $18 \mu \mathrm{g}$ of pMMrasDN and $2 \mu \mathrm{g}$ of pRSV-neo. Neomycin-resistant clones were isolated as described above and screened on the basis of the ability of dexamethasone to inhibit NGF-induced neurite outgrowth. Two clones, GSrasDN6 and GSrasDN13, were chosen for this study and were further characterized by Northern blot analysis (see Results). The PC12 subline $17 \mathrm{~N}-2$, which expresses transfected $\mathrm{p} 21^{\mathrm{N} 17}$ Ras under the control of the Moloney murine leukemia virus long terminal repeat, was isolated as previously described (47).

Northern blot analysis. Total cellular RNA was isolated from $\mathrm{PC} 12$ or $\mathrm{PC} 12$ subclones essentially by the method of Cathala et al. (4). RNA samples (10 $\mu \mathrm{g}$ per lane) were electrophoresed through agarose gels containing $2.2 \mathrm{M}$ formaldehyde, $40 \mathrm{mM}$ morpholinepropanesulfonic acid (MOPS) buffer ( $\mathrm{pH} 7$ ), $10 \mathrm{mM}$ sodium acetate, and $1 \mathrm{mM}$ EDTA and then electrophoretically transferred to nylon membranes (Duralon-UV; Stratagene). The blots were cross-linked by using a Stratalinker UV cross-linker (Stratagene) and hybridized to $\left[\alpha-{ }^{32} P\right]$ UTP-labeled antisense RNA probes in hybrid- ization buffer containing $5 \times \mathrm{SSC}(1 \times \mathrm{SSC}$ is $0.15 \mathrm{M} \mathrm{NaCl}$ plus $0.015 \mathrm{M}$ sodium citrate), $1 \times$ Denhardt's solution, 20 mM sodium phosphate, $50 \%$ formamide, $0.5 \%$ sodium dodecyl sulfate (SDS), and $0.1 \mathrm{mg}$ of denatured salmon sperm DNA per ml at $68^{\circ} \mathrm{C}$ for 16 to $24 \mathrm{~h}$. RNA probes were synthesized by using as templates the following linearized cDNA clones: pMJC18, encoding v-ras (kindly provided by M. Corbley and T. Roberts); NGFI-A (39) subcloned into pBluescript KS (kindly provided by J. Milbrandt); pGTTR1, encoding transin (38), subcloned into pGEM7Zf (+) (kindly provided by L. M. Matrisian); VGF8a, encoding VGF (31), subcloned into pSP64 (kindly provided by A. Levi); Thy-1 (23) subcloned into pSP65 (kindly provided by G. A. Evans); pRB211 (7), encoding sodium channel (kindly provided by G. Mandel); and pIB15 (8), encoding cyclophilin. All riboprobes were generated according to the manufacturer's instructions by using SP6 polymerase (Promega) except for the NGFI-A riboprobe, which was generated by using T7 polymerase (Boehringer Mannheim). The blots were washed once in $1 \times \mathrm{SSC}-0.1 \% \mathrm{SDS}$ at $68^{\circ} \mathrm{C}$ and twice in $0.1 \times$ SSC $-0.1 \%$ SDS for $20 \mathrm{~min}$ at $68^{\circ} \mathrm{C}$ and then subjected to autoradiography with preflashed Kodak XAR-5 films. Levels of gene expression were determined by densitometric analysis, and all values were normalized to the autoradiographic density corresponding to cyclophilin mRNA.

\section{RESULTS}

Induction of NGFI-A, transin, and VGF genes is mediated by Trk, Src, Ras, and Raf activities. NGFI-A (also known as TIS8, zif/268, Egr-1, d2, PC1, and Krox24) is a primaryresponse gene which is induced rapidly upon NGF treatment of PC12 cells (39). It has been shown previously that either activation of $\mathbf{v}$-Src tyrosine kinase or expression of an activated serine/threonine Raf-1 kinase increases the level of NGFI-A mRNA in PC12 sublines expressing these oncogenes $(56,58)$. Since we have postulated that Ras action lies between Src and Raf actions in mediating neurite outgrowth, we predicted that the expression of an activated ras oncogene in PC12 cells would also induce NGFI-A expression. We examined the effect of activated Ras on NGFI-A gene expression in two PC12 sublines, GSras1 or GSras2, which contain a transfected ras oncogene under the control of the inducible MMTV promoter (see Materials and Methods). As shown in Fig. 1A, GSras1 cells express, in addition to the endogenous c-ras mRNA, a dexamethasone-inducible ras transcript corresponding to the p21 ${ }^{\mathrm{L} 61} \mathrm{mRNA}$ encoded by the transfected plasmid. Expression of the oncogenic ras transcript could be detected as early as $2 \mathrm{~h}$ and was maximal after $4 \mathrm{~h}$ of dexamethasone treatment. The induction of ras mRNA in GSras2 cells was qualitatively similar to that observed in GSras1 cells although of lower magnitude, which correlated with the smaller extent of neurite outgrowth observed in these cells (not shown). Dexamethasone treatment of GSras1 cells resulted in a time-dependent accumulation of NGFI-A mRNA. As early as $1 \mathrm{~h}$ after dexamethasone addition, an increase in NGFI-A mRNA was observed, with peak levels corresponding to about 80 -fold induction occurring within $6 \mathrm{~h}$ (Fig. 2A). The kinetics of NGFI-A mRNA induction paralleled expression of the MMTV ras oncogene (Fig. 1A). Similar results were obtained with GSras2 cells (not shown). Since dexamethasone treatment of PC12 cells did not elevate NGFI-A mRNA levels (Fig. 2B), these data indicate that activated Ras, like activated Src and Raf and NGF treatment, stimulates NGFI-A gene expression. 

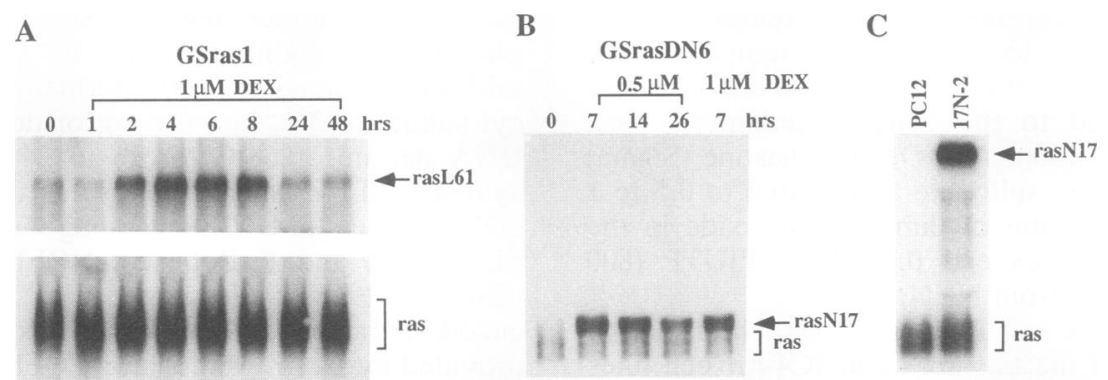

FIG. 1. Time course of expression of mutant ras transcripts in stable PC12-derived transfectants. GSras1 (A) or GSrasDN6 (B) cells were incubated in the presence of 0.5 or $1 \mu \mathrm{M}$ dexamethasone (DEX) for the indicated times. Total RNA was isolated and subjected to Northern blot analysis as described in Materials and Methods. Samples were electrophoresed through $0.8 \%$ (A), $1.5 \%$ (B), or $1 \%$ (C) agarose gels. Blots were hybridized to a riboprobe generated from linearized pMJC18 and directed against ras sequences. Arrows indicate ras mutant transcripts encoding $\mathrm{p} 21^{\mathrm{L} 61}$ in GSras1 cells $(\sim 8 \mathrm{~kb})$ or $\mathrm{p} 21^{\mathrm{N} 17}$ in GSrasDN6 $(\sim 1.5 \mathrm{~kb})$ and $17 \mathrm{~N}-2(\sim 7 \mathrm{~kb})$ cells. The positions of endogenous ras mRNAs (1 to $1.4 \mathrm{~kb})$ are indicated by brackets.

To determine whether c-Ras is required for NGF-stimulated expression of the NGFI-A gene, we examined the ability of NGF to stimulate NGFI-A mRNA production in two PC12 sublines, GSrasDN6 or GSrasDN13, which express the dominant negative Ras mutant $\mathrm{p} 21^{\mathrm{N} 17}$ Ras under the control of the inducible MMTV promoter (see Materials and Methods). The p $21^{\mathrm{N} 17}$ Ras mutant binds GDP with an affinity higher than that for GTP and appears to compete with the endogenous p21 Ras for upstream activators, but it lacks the capacity to propagate the signal (12). Maximal expression of dominant negative ras mRNA in clone GSrasDN6 was achieved after $7 \mathrm{~h}$ of 0.5 or $1 \mu \mathrm{M}$ dexamethasone treatment and reached a level sixfold above that of the combined endogenous c-ras mRNAs (Fig. 1B). Transfected mutant ras mRNA decreased to half-maximal levels by $26 \mathrm{~h}$. The time course and dose response of dexamethasoneinduced ras expression in GSrasDN13 cells were similar to those for GSrasDN6 cells (not shown). In GSrasDN6, as in parental PC12 cells, NGF stimulated the production of NGFI-A RNA by over 100-fold within $1 \mathrm{~h}$ (Fig. 2B). After treatment with dexamethasone, NGF stimulation of NGFI-A mRNA accumulation in GSrasDN6 cells was attenuated by $80 \%$ (Fig. 2B). Similar results were obtained with GSrasDN13 cells (not shown). In contrast, dexamethasone treatment of parental PC12 cells did not significantly affect NGF-stimulated NGFI-A gene expression (Fig. 2B) (53).

The ability of NGF to stimulate accumulation of NGFI-A mRNA was also examined in another PC12 subline, $17 \mathrm{~N}-2$, which constitutively expresses the dominant negative p $21^{\mathrm{N} 17}$ Ras under the control of the Moloney murine leukemia virus long terminal repeat. $17 \mathrm{~N}-2$ cells express, in addition to the endogenous ras mRNAs, an exogenous ras transcript encoding transfected p $21^{\mathrm{N} 17}$ Ras (Fig. 1C). The abundance of the mutant $\mathrm{ras}^{\mathrm{N} 17}$ transcript is at least twofold greater than that of the combined endogenous ras mRNAs, an amount sufficient to account for the competitive inhibition of c-Ras by the mutant Ras p21 ${ }^{\mathrm{N} 17}$. The level of NGFI-A mRNA after NGF treatment of $17 \mathrm{~N}-2$ cells was less than $2 \%$ of that seen in PC12 cells (Fig. 2B). This result cannot be attributed to a lower responsiveness of this $\mathrm{PC} 12$ subline to NGF, since other NGF induction events (see below) are normal. Taken together, these data indicate that NGFI-A induction by NGF is largely dependent on c-Ras activity.

Genes induced by NGF are characterized by distinct time dependencies. In contrast to immediate-early genes like NGFI-A, which are rapidly and transiently induced even in the absence of protein synthesis, another class of gene induction event occurs over a longer time course and requires protein synthesis. Transin (stromelysin), an example of a late-response gene, is robustly induced by NGF in PC12 cells (34). In contrast to the originally reported peak time of

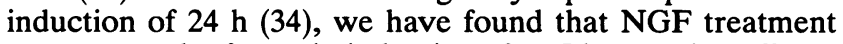
causes a peak of transin induction after $5 \mathrm{~h}$, tapering off to a lower level of induction within $24 \mathrm{~h}$, in agreement with a recent report (22). We have reported that transin mRNA is dramatically induced upon expression of the activated Raf oncoprotein (58). To determine whether transin, like NGFI-A, is induced by activated Src, we used a PC12 subline, ts:v-src3, which constitutively expresses a transfected temperature-sensitive mutant of v-src (NY72-4 [56]). In uninduced ts: $v$-src 3 cells, as in parental PC12 cells, basal expression of transin mRNA was undetectable. Activation
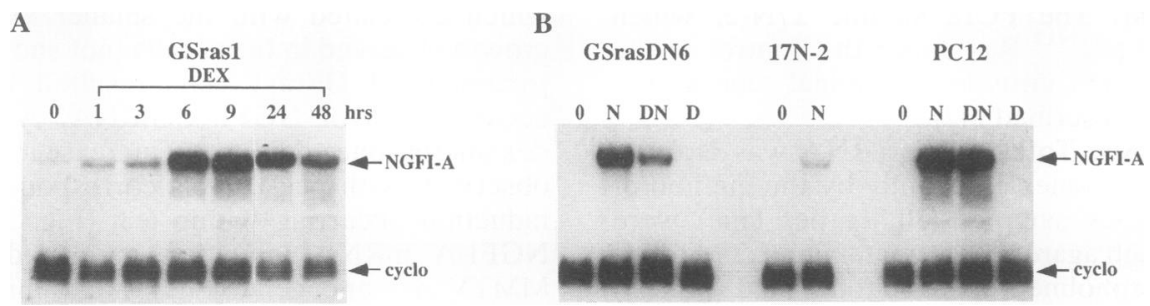

FIG. 2. Ras-mediated NGF induction of NGFI-A gene expression. (A) GSras1 cells were treated with $0.5 \mu \mathrm{M}$ dexamethasone (DEX) for the indicated times; (B) GSrasDN6, 17N-2, and PC12 cells were incubated with NGF for $1 \mathrm{~h}(\mathrm{~N})$, preincubated with $0.5 \mu \mathrm{M}$ dexamethasone for $16 \mathrm{~h}$, and then treated with NGF for $1 \mathrm{~h}$ (DN) or treated with $0.5 \mu \mathrm{M}$ dexamethasone alone for $16 \mathrm{~h}$ (D). Total RNA was isolated and subjected to Northern blot analysis as described in Materials and Methods. Samples were electrophoresed through 1\% agarose gels. Blots were hybridized to riboprobes directed against NGFI-A (3.3 kb) and the internal control cyclophilin (cyclo; $1 \mathrm{~kb})$. 

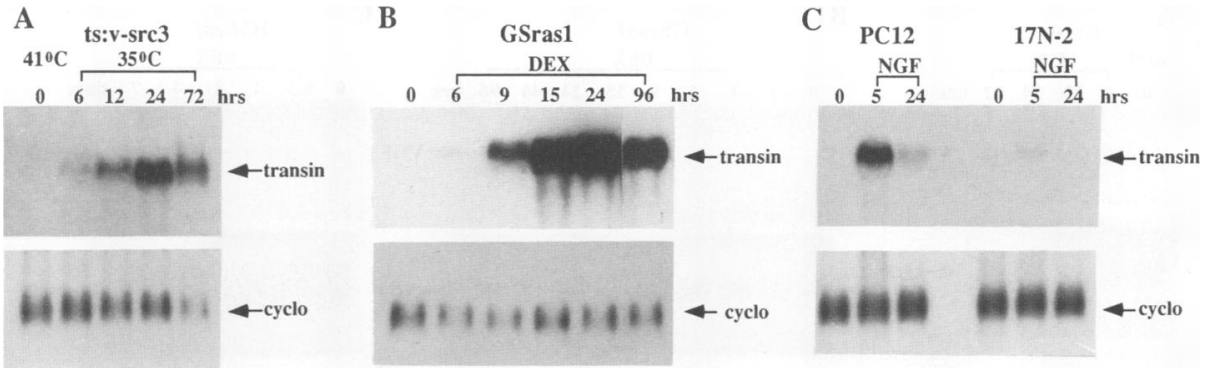

FIG. 3. Src- and Ras-mediated NGF induction of transin gene expression. (A) ts:v-src3 cells were shifted from the nonpermissive temperature of $41^{\circ} \mathrm{C}$ to the permissive temperature of $35^{\circ} \mathrm{C}$ for the indicated times; (B and C) GSrasl cells were incubated with $0.5 \mu \mathrm{M}$ dexamethasone (DEX) (B) and PC12 and 17N-2 cells were incubated with NGF (C) for the indicated times. Total RNA was isolated and subjected to Northern blot analysis as described in Materials and Methods. Samples were electrophoresed through $0.8 \%$ (A and C) or $1 \%$ (B) agarose gels. Blots were hybridized to riboprobes directed against transin $(1.9 \mathrm{~kb})$ and the internal control cyclophilin (cyclo; $1 \mathrm{~kb})$.

of the temperature-sensitive v-Src kinase by shifting ts: $v$ $s r c 3$ cells from the nonpermissive temperature $\left(41^{\circ} \mathrm{C}\right)$ to the permissive temperature $\left(35^{\circ} \mathrm{C}\right)$ resulted in a large increase in transin mRNA levels (Fig. 3A). This increase was analogous to that seen by NGF treatment of parental PC12 cells. The transin transcript was first detectable after $6 \mathrm{~h}$ of $\mathrm{v}$-Src activation and peaked after approximately $24 \mathrm{~h}$. Induction of the MMTV-ras oncogene also resulted in a large induction of transin mRNA levels (Fig. 3B). The transin transcript, undetectable in untreated GSras1 cells, began to accumulate after $9 \mathrm{~h}$ of dexamethasone treatment, reaching a maximal level by $24 \mathrm{~h}$. Similar results were obtained with GSras 2 cells (not shown). This stimulatory effect can be attributed to the activity of the Ras oncoprotein because dexamethasone treatment does not induce transin expression in PC12 cells (34). The extent of induction by oncogenic Ras was comparable to that obtained by NGF treatment of PC12 cells (Fig. 3C). To investigate the possibility that c-Ras is required for NGF induction of transin gene expression, we measured the level of NGF-induced transin mRNA in $17 \mathrm{~N}-2$ cells, which constitutively express the dominant negative mutant $\mathrm{p} 21^{\mathrm{N} 17}$ Ras. As shown in Fig. 3C, the level of transin mRNA in NGF-treated $17 \mathrm{~N}-2$ cells was only $2 \%$ of that seen in parental PC12 cells, indicating that c-Ras is required for NGF-induced transin gene expression. This result could not be verified in the subclones inducibly expressing $\mathrm{p} 21^{\mathrm{N} 17}$ because of the strong inhibitory effect of dexamethasone on NGF-induced transin expression (34; data not shown); however, it is consistent with a previous study in which a different PC12 subclone overexpressing p21 ${ }^{\mathrm{N} 17}$ Ras was used (53).

The VGF gene (also known as a2 and NGF33.1) was identified on the basis of NGF inducibility in PC12 cells. NGF treatment increased the level of VGF mRNA in PC12 cells by approximately 20 -fold, reaching a peak level within 5 to $6 \mathrm{~h}$ of continuous NGF treatment and then slowly declining thereafter (Fig. 4E) $(31,48)$. Induction of this gene is partially dependent upon protein synthesis, a feature which distinguishes it from both immediate-early genes and late-response genes $(3,44)$. To determine whether an activated Src tyrosine kinase was able to elicit VGF gene induction, we examined VGF mRNA levels at different times after activation of the temperature-sensitive $v$-Src kinase. In ts:v-src 3 cells, shifted from growth at the nonpermissive $\left(41^{\circ} \mathrm{C}\right)$ to the permissive temperature $\left(35^{\circ} \mathrm{C}\right)$, VGF mRNA levels increased within $6 \mathrm{~h}$ and peaked at about sevenfold above baseline within $24 \mathrm{~h}$ (Fig. 4A). However, the levels of VGF mRNA were higher basally, and the induction was of a lower magnitude and over a slower time course compared with NGF induction of VGF mRNA in parental PC12 cells. This finding may in part be attributed to the incomplete inactivation of the temperature-sensitive $\mathrm{v}$-Src kinase activity at the nonpermissive temperature (56).

To determine whether activated, oncogenic Ras could induce the VGF gene, VGF mRNA was examined in GSras1 cells. VGF mRNA accumulated with a time course which followed that of induction of oncogenic ras mRNA (compare Fig. 1A and 4B); the VGF gene was induced within $6 \mathrm{~h}$ of dexamethasone treatment, reaching a peak of 15 - to 20 -fold above baseline after about 1 day. Similar results were obtained with GSras 2 cells (not shown). Because dexamethasone treatment of PC12 cells alone (not shown) or in combination with NGF (Fig. 4D) did not significantly increase VGF gene expression, the induction of this gene in GSras1 or GSras2 cells can be attributed to the activity of oncogenic Ras.

The possible induction of VGF mRNA by activated, oncogenic Raf kinase was examined in IC4-raf cells. Dexamethasone treatment of these cells has been shown to stimulate expression of the transfected MMTV-raf hybrid gene, with raf mRNA and protein levels peaking after 6 to 8 $h$ (58). In IC4-raf cells, the increase in VGF mRNA levels by dexamethasone-induced oncogenic Raf was first observed within $8 \mathrm{~h}$ of treatment. VGF mRNA was induced robustly by activated Raf ( 20 -fold) but over a longer time course compared with NGF. Raf-induced VGF mRNA reached a maximal level after about 4 days of dexamethasone treatment (Fig. 4C).

The data presented above indicated that activated Src, Ras, and Raf oncoproteins are each sufficient to induce VGF mRNA in PC12 cells. To assess the requirement for c-Ras activity in mediating NGF induction of the VGF gene, we measured the ability of NGF to stimulate VGF mRNA production in the PC12 subclones GSrasDN6 and GSras DN13. After treatment of these cells with dexamethasone to induce $\mathrm{p} 21^{\mathrm{N} 17}$ Ras, NGF-induced VGF expression was inhibited by about $60 \%$ (Fig. 4D and data not shown). A similar dexamethasone treatment of parental PC12 cells did not significantly affect VGF induction by NGF (Fig. 4D). In $17 \mathrm{~N}-2$ cells, which constitutively express the inhibitory Ras mutant $\mathrm{p} 21^{\mathrm{N} 17}$, NGF treatment resulted in only a twofold induction of VGF mRNA levels, equivalent to approximately $10 \%$ of the NGF-induced level seen in PC12 cells (Fig. 4E), further indicating that c-Ras is required for NGF induction of VGF gene expression.

Induction of the SCG10 gene reveals a branchpoint off Ras. 

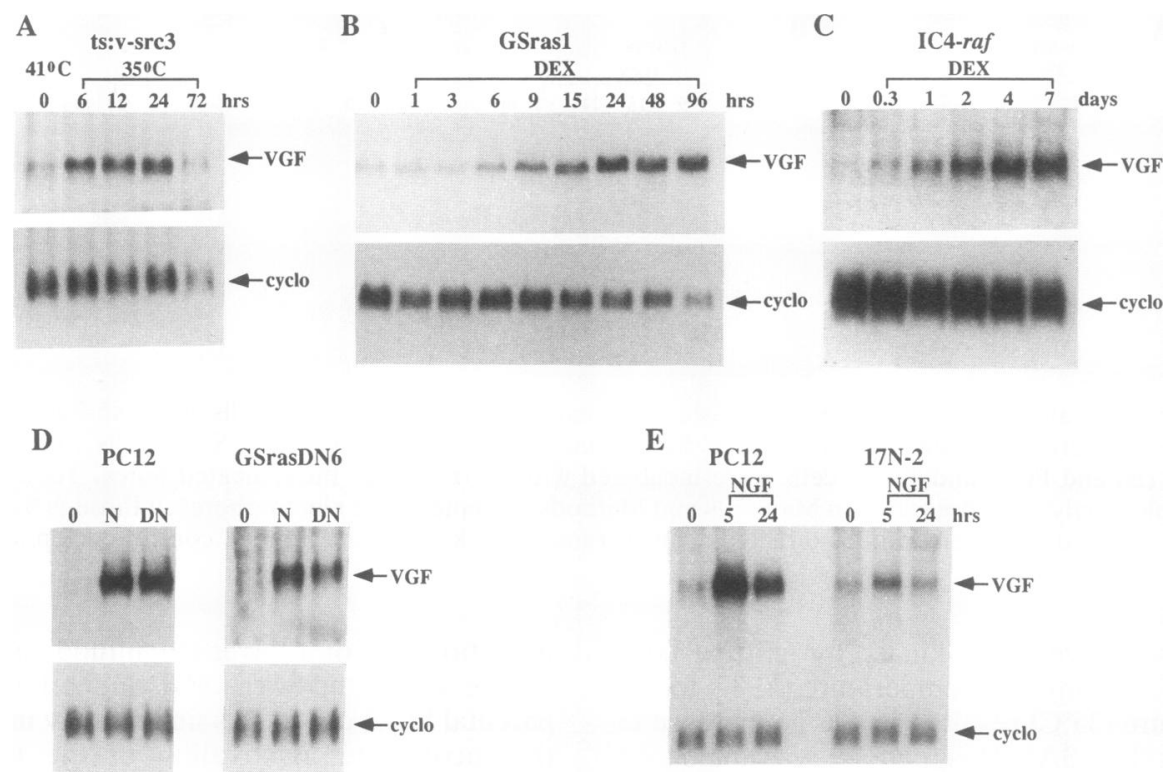

FIG. 4. Src-, Ras-, and Raf-mediated NGF induction of VGF gene expression. (A) ts:v-src3 cells were shifted from the nonpermissive temperature of $41^{\circ} \mathrm{C}$ to the permissive temperature of $35^{\circ} \mathrm{C}$ for the indicated times; (B and C) GSras1 (B) or IC4-raf (C) cells were incubated with $0.5 \mu \mathrm{M}$ dexamethasone (DEX) for the indicated times; (D) GSrasDN6 and PC12 cells were treated for $5 \mathrm{~h}$ with NGF alone (N) or preincubated with $0.5 \mu \mathrm{M}$ dexamethasone for $16 \mathrm{~h}$ and then treated with $5 \mathrm{~h}$ with NGF (DN); (E) PC12 and 17N-2 cells were treated with NGF for the indicated times. Total RNA was isolated and subjected to Northern blot analysis as described in Materials and Methods. Samples were electrophoresed through $0.8 \%(\mathrm{~A}, \mathrm{C}, \mathrm{D}$, and $\mathrm{E})$ or $1 \%(\mathrm{~B})$ agarose gels. Blots were hybridized to riboprobes directed against VGF (2.7 $\mathrm{kb})$ and the internal control cyclophilin (cyclo; $1 \mathrm{~kb}$ ).

Expression of the late-response gene SCG10 is induced by approximately fivefold after NGF treatment of PC12 cells for $24 \mathrm{~h}$ (Fig. 5C) (51). We have previously shown that activation of oncogenic Src in ts: $v$-src3 cells leads to increased SCG10 mRNA levels, with a time course very similar to that seen in response to NGF (56). Expression of activated Ras in the GSras1 or GSras2 cells also resulted in an induction of SCG10 mRNA levels (Fig. 5A and data not shown). Increased expression of SCG10 in GSras1 cells was first noticeable after 1 day of dexamethasone treatment and further increased to sixfold above baseline after 3 days, in spite of the half-maximal inhibition of SCG10 basal expression seen in PC12 cells in response to the steroid (51). In contrast to Src and Ras, activated Raf expression after dexamethasone treatment of IC4-raf cells did not result in increased SCG10 expression. Analysis of the same IC4-raf samples which showed dramatically induced levels of VGF mRNA (Fig. 4C) did not indicate any increase in SCG10 mRNA levels (Fig. 5B), even though basal levels of SCG10 mRNA were similar to those seen in the parental PC12 cells (data not shown). Furthermore, NGF treatment of IC4-raf cells resulted in a normal induction of SCG10 (Fig. 5B), suggesting that the intracellular mechanisms required to elevate SCG10 expression in these cells were not disrupted. As with parental PC12 cells (51), dexamethasone treatment of IC4-raf cells resulted in a reduction of SCG10 mRNA levels (Fig. 5B).

To assess the requirement for c-Ras activity in mediating NGF induction of the SCG10 gene, we measured the ability of NGF to stimulate SCG10 mRNA accumulation in the PC12 sublines GSrasDN6, GSrasDN13, and 17N-2, which express p21 ${ }^{\mathrm{N} 17}$ Ras. Dexamethasone treatment of GSrasDN6 or GSrasDN13 cells, as in PC12 cells, resulted in a reduction of SCG10 mRNA to less than basal levels.

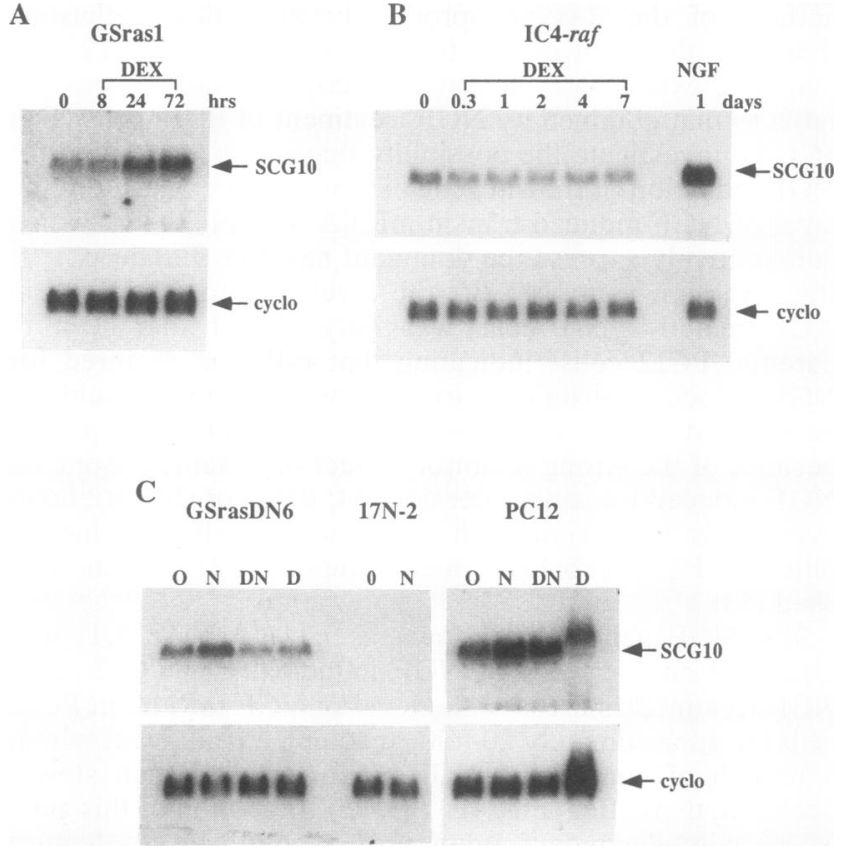

FIG. 5. Mediation by Ras, but not Raf, of NGF induction of SCG10 gene expression. (A and B) GSras1 (A) or IC4-raf (B) cells were incubated in the presence of $0.5 \mu \mathrm{M}$ dexamethasone (DEX) or NGF, as indicated; (C) GSrasDN6, 17N-2, and PC12 cells were incubated with NGF for $24 \mathrm{~h}(\mathrm{~N})$, preincubated with $0.5 \mu \mathrm{M}$ dexamethasone for $16 \mathrm{~h}$, and then treated with NGF for $24 \mathrm{~h}(\mathrm{DN})$ or treated with $0.5 \mu \mathrm{M}$ dexamethasone alone for $16 \mathrm{~h}(\mathrm{D})$. Total RNA was isolated and subjected to Northern blot analysis as described in Materials and Methods. Samples were electrophoresed through $1 \%$ agarose gels. Blots were hybridized to riboprobes directed against SCG10 (1.9 kb) and the internal control cyclophilin (cyclo; $1 \mathrm{~kb})$. 

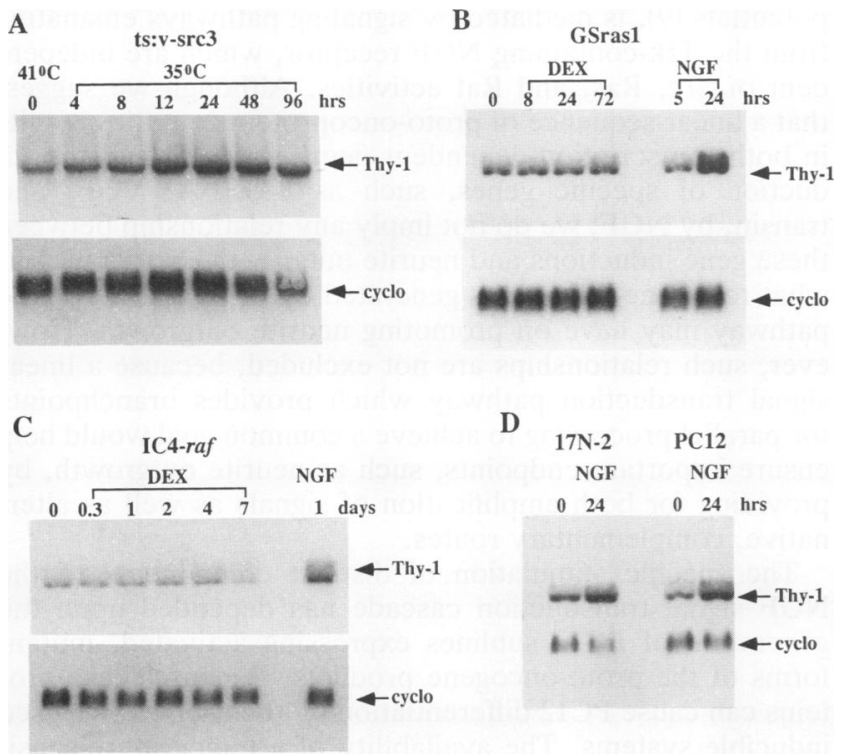

FIG. 6. Mediation by Src, but not Ras or Raf, of NGF induction of Thy-1 gene expression. (A) ts:v-src3 cells were shifted from the nonpermissive temperature of $41^{\circ} \mathrm{C}$ to the permissive temperature of $35^{\circ} \mathrm{C}$ for the indicated times; (B and C) GSras1 (B) or IC4-raf (C) cells were incubated $i n$ the presence of $0.5 \mu \mathrm{M}$ dexamethasone (DEX) or NGF for the indicated times; (D) $17 \mathrm{~N}-2$ and PC12 cells, as indicated, were incubated with NGF. Total RNA was isolated and subjected to Northern blot analysis as described in Materials and Methods. Samples were electrophoresed through 1\% agarose gels. Blots were hybridized to riboprobes directed against Thy-1 $(1.8 \mathrm{~kb})$ and the internal control cyclophilin (cyclo; $1 \mathrm{~kb}$ ).

However, in contrast to PC12, complete inhibition of NGFinduced SCG10 expression was observed in the dexamethasone-treated GSrasDN6 (Fig. 5C) and GSrasDN13 (not shown) cells. In dexamethasone-treated PC12 cells, NGF induction of SCG10 mRNA was inhibited by only approximately 50\% (Fig. 5C). Control and NGF-treated 17N-2 cells do not express any detectable SCG10 mRNA (Fig. 5C). This result is in agreement with similar findings in different $\mathrm{PC} 12$ sublines expressing dominant negative Ras (53).

Induction of the Thy-1 gene reveals a branchpoint off Src. Thy-1 is a late-response gene which is upregulated three- to fourfold within $24 \mathrm{~h}$ of NGF treatment (Fig. 6D) (11). Activation of the $\mathrm{v}$-Src tyrosine kinase by temperature downshift of the ts: $v$-src 3 cells resulted in a 2.5 -fold increase in Thy-1 mRNA levels by $12 \mathrm{~h}$ (Fig. 6A). This induction, similar to that obtained by NGF, suggests that activation of the v-Src kinase mimics NGF in inducing expression of Thy-1. However, expression of either activated Ras or Raf failed to increase the level of Thy-1 mRNA. GSras1, GSras2, and IC4-raf cells expressed normal basal levels of Thy-1 mRNA compared with PC12 cells, examined on a single Northern blot (not shown). Dexamethasone treatment of either GSras1 (Fig. 6B), GSras2 (not shown), or IC4-raf (Fig. 6C) cells did not increase Thy-1 expression, suggesting that activation of Ras or Raf alone is not sufficient to trigger this effect. NGF treatment did, however, result in a normal increase in Thy-1 expression in these cells (Fig. 6B and C and data not shown), indicating that the NGF-stimulated pathways to Thy-1 gene induction were intact. To determine whether c-Ras is required for NGF-induced Thy-1 gene expression, we compared levels of Thy-1 mRNA in $17 \mathrm{~N}-2$
A

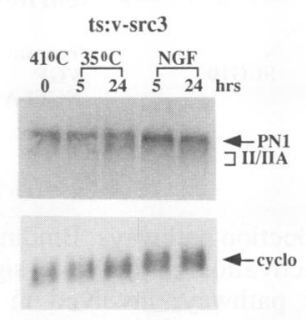

C

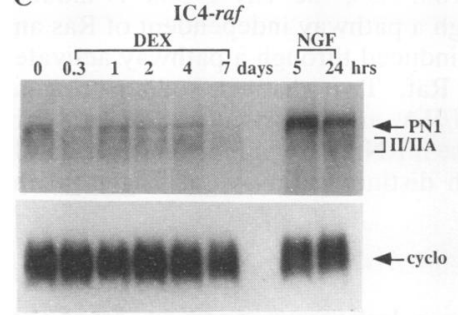

B

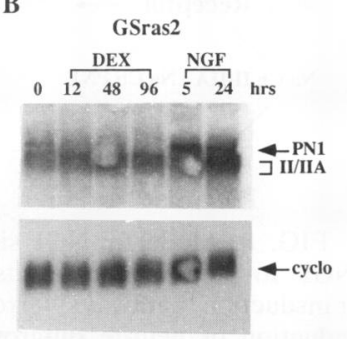

FIG. 7. Inability of Src, Ras, and Raf to mediate NGF induction of sodium channels gene expression. (A) ts:v-src3 cells were shifted from the nonpermissive temperature of $41^{\circ} \mathrm{C}$ to the permissive temperature of $35^{\circ} \mathrm{C}$ or treated with NGF for the indicated times; (B and C) GSras2 (B) or IC4-raf (C) cells were treated with $0.5 \mu \mathrm{M}$ dexamethasone (DEX) or NGF for the indicated times; (D) $17 \mathrm{~N}-2$ and PC12 cells were incubated with NGF for the indicated times. Total RNA was isolated and subjected to Northern blot analysis as described in Materials and Methods. Samples were electrophoresed through $0.8 \%$ agarose gels. Blots were hybridized to riboprobes directed against sodium channel mRNAs (pRB211) and the internal control cyclophilin (cyclo; $1 \mathrm{~kb}$ ). The positions of sodium channel type PN1 (11 kb) and type II/IIA (9.5 to $10.5 \mathrm{~kb})$ are indicated.

and PC12 cells. NGF caused a similar increase in Thy-1 mRNA levels in both PC12 cells and $17 \mathrm{~N}-2$ cells (Fig. 6D), in sharp contrast to the other genes discussed above.

NGF induction of sodium channel genes is not mediated by Src, Ras, or Raf activity. Treatment of PC12 cells with NGF increases the expression of two different sodium channel mRNAs, termed types PN1 and II/IIA $(9,36)$. These mRNAs are differentially upregulated by NGF, with maximal mRNA levels (three- to fivefold) reached by $5 \mathrm{~h}$ and 1 day, respectively. These mRNAs can be detected with a probe which recognizes a sequence conserved in all known sodium channel mRNAs (7). Levels of sodium channel type PN1 mRNA were unaffected by either activation of the v-Src kinase in ts:v-src3 cells (Fig. 7A), activated Ras expression in GSras2 cells (Fig. 7B), or activated Raf expression in IC4-raf cells (Fig. 7C). In contrast, levels of this mRNA were induced after $5 \mathrm{~h}$ of NGF treatment in these cell lines, although to a lower extent in the ts:v-src3 cells (Fig. 7A to C). The small magnitude of NGF-mediated gene induction in ts: $v$-src3 cells reflects a generally lower responsiveness of this cell line to NGF in all differentiation parameters examined (data not shown). A small induction of type II/IIA (less than twofold) was observed after activation of each oncogene (Fig. 7A to C). However, at least in GSras2 and IC4-raf cells, this effect was significantly smaller than that observed after 24-h treatment of each cell line with NGF (Fig. 7B and C). NGF treatment of ts:v-src3 cells did not result in any type II/IIA mRNA induction (Fig. 7A), which may be 


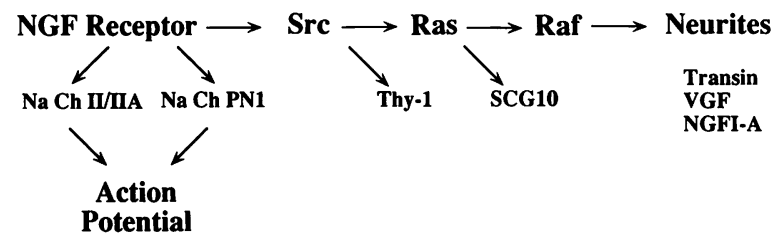

FIG. 8. Model for NGF signal transduction pathways. Binding of NGF to its receptor results in the activation of multiple signal transduction pathways (arrows). One pathway, involved in the induction of neurite outgrowth and the increased expression of several genes such as NGFI-A, VGF, and transin, consists of a linear cascade of Src, Ras, and Raf activities. Branchpoints off this cascade arise from Src and from Ras; the Thy-1 gene is induced following Src activation through a pathway independent of Ras and Raf, while the SCG10 gene is induced through a pathway activated by Ras and independent of Raf. Two distinct sodium channel mRNAs, type PN1 and type II/IIA, are important for the establishment of action potentials. These mRNAs are induced independently of Src, Ras, and Raf, through distinct pathways arising from the NGF receptor.

attributed at least in part to a lower responsiveness of this cell line to NGF.

To determine whether c-Ras activity is required for NGFinduced sodium channel gene expression, we examined sodium channel mRNAs in the $17 \mathrm{~N}-2$ cell line. As in parental PC12 cells, levels of both sodium channel type PN1 and type II/IIA mRNAs were increased in $17 \mathrm{~N}-2$ cells upon NGF treatment (Fig. 7D), although the induction of type PN1 mRNA measured from several experiments was measurably smaller in $17 \mathrm{~N}-2$ cells (two- to threefold) than in parental PC12 cells (three- to fivefold).

\section{DISCUSSION}

This study has assayed gene induction events in order to map the signal transduction pathways emanating from the NGF receptor to the nucleus in PC12 cells. The following conclusions may be drawn from our data. (i) NGF induction of three genes, NGFI-A, VGF, and transin, can be mimicked by activated forms of Src, Ras, and Raf oncoproteins and requires endogenous c-Ras activity. (ii) NGF induction of SCG10 is mimicked by activated forms of Src and Ras oncoproteins, but not by activated Raf, and requires endogenous c-Ras activity. (iii) NGF induction of Thy-1 is mimicked by activated Src, but not by activated Ras or Raf, and does not require endogenous c-Ras activity. (iv) NGF induction of two sodium channel mRNAs, type PN1 and type II/IIA, is not mimicked by activated forms of Src, Ras, and Raf oncoproteins and is largely independent of endogenous c-Ras activity.

We propose a model for NGF signal transduction which takes into account previous studies on the involvement of proto-oncogenes in NGF-induced neurite outgrowth $(30,58)$ and present results on specific gene induction events (Fig. 8). In this model, NGF stimulates a linear signaling cascade of activities beginning with the Trk-containing NGF receptor and including a sequence of Src, Ras, and Raf proteins which ultimately leads to neurite outgrowth and the induction of NGFI-A, VGF, and transin genes. Several branchpoints off this pathway also lead to specific gene induction events. For example, the Thy-1 gene is induced off a Src branchpoint and the SCG10 gene is induced off a Ras branchpoint. The induction of sodium channel mRNAs for type PN1 and type II/IIA, which is responsible for the ability to generate action potentials (9), is mediated by signaling pathways emanating from the Trk-containing NGF receptor, which are independent of Src, Ras, and Raf activities. Although we suggest that a linear sequence of proto-oncoprotein activities results in both transcription-dependent neurite growth and the induction of specific genes, such as NGFI-A, VGF, and transin, by NGF, we do not imply any relationship between these gene inductions and neurite outgrowth. Nor is it clear what role gene inductions generated by branchpoints in the pathway may have on promoting neurite outgrowth. However, such relationships are not excluded, because a linear signal transduction pathway which provides branchpoints for parallel processing to achieve a common goal would help ensure important endpoints, such as neurite outgrowth, by providing for both amplification of signals as well as alternative, complementary routes.

The specific stimulation of distinct components of the NGF signal transduction cascade has depended upon the generation of $\mathrm{PC} 12$ sublines expressing activated, mutant forms of the proto-oncogene products. Because these proteins can cause PC12 differentiation by themselves, we used inducible systems. The availability of a temperature-sensitive mutant of v-src has allowed us to activate this Src kinase by a subtle manipulation of the cell growth conditions. To activate Ras or Raf, we expressed these oncoproteins from the dexamethasone-inducible MMTV promoter. Although this approach has achieved the required result, it presents two drawbacks. First, the time course of Ras or Raf oncoprotein induction by dexamethasone is slow relative to the rapid activation of the proto-oncoprotein counterparts by NGF; this may explain in part the slower time course of gene inductions, such as for NGFI-A and VGF, seen in response to oncogenic Ras and Raf expression. The second drawback lies in the use of dexamethasone as the oncogene inducer. This steroid has pleiotropic actions on PC12 cells which include antagonistic effects on some NGF gene inductions. Partial inhibition of NGF induction of the SCG10 gene and a complete inhibition of transin gene induction by dexamethasone have been previously reported $(34,51)$ and confirmed herein. NGF-induced Thy-1 expression is also partially, but significantly, inhibited by dexamethasone (not shown). The ras oncogene product $\mathrm{p} 21^{\mathrm{L} 61}$ overcomes the inhibitory effects of dexamethasone of the SCG10 and transin genes, in part perhaps by reducing the number of glucocorticoid receptors (37). The raf oncogene product also overcomes the inhibitory effect of dexamethasone on transin gene induction (58). Thus, the inability of oncogenic Ras to induce the Thy-1 gene and the inability of oncogenic Raf to induce the Thy-1 or SCG10 gene likely reflects the lack of involvement of these proteins rather than an inhibitory effect of dexamethasone. This conclusion is supported by the differential ability of the constitutively expressed dominant inhibitory Ras p $21^{\mathrm{N} 17}$ in $17 \mathrm{~N}-2$ cells to inhibit NGF induction of these genes.

The extent to which activated Src, Ras, and Raf mediate gene expression is consistent with the hierarchical nature of signaling observed with respect to neurite growth $(30,58)$. These observations argue in favor of a proto-oncoprotein pathway which differentially generates signals for distinct gene inductions. Our assignment of branchpoints in the pathway results from both the observed inability of activated, oncoproteins to induce certain genes and the inability of a dominantly interfering Ras mutant to prevent specific gene inductions by NGF. For example, activated Src and Ras oncoproteins are sufficient for SCG10 gene induction, and endogenous Ras activity is also essential for NGF 
induction of this gene. The insufficiency of the Raf oncoprotein to induce SCG10 therefore suggests that Raf activity is not involved; however, it remains possible that a Raf activity may still be required to act in concert with other Rasdependent pathways. In the case of the Thy-1 gene, induction is not mediated by activated forms of the Ras or Raf oncoprotein. However, the finding that Thy-1 gene induction by NGF is not impaired by a dominantly interfering form of Ras strongly suggests that this gene, unlike many others, is regulated by signals generated upstream of $c-R a s$ and is thus independent of this activity. In a similar way, neither Src nor Ras nor Raf activation is sufficient to induce sodium channel genes in PC12 cells, and c-Ras activity is also not necessary for NGF induction of these genes. However, we cannot rule out a possible involvement of, for example, Src activity which may work only in conjunction with a distinct pathway generated by the NGF receptor. We have further noted that activated oncogenic forms of Src, Ras, or Raf elicit gene inductions with time courses that are quite different from those observed in response to NGF treatment. For example, expression of the Raf oncoprotein results in significantly longer time courses of induction of NGFIA, transin, and VGF than does NGF treatment, as it does with other differentiation parameters such as neurite outgrowth (58). This might be explained by the likelihood that oncogenic proteins may not faithfully mimic the activities of their cellular counterparts. Alternatively, these different time courses may well indicate that other pathways act in conjunction with Raf to generate the normal pattern of differentiation. A similar argument may be made for the unusually long time course of transin induction by activated Src, Ras, and Raf oncoproteins. However, in this case, Ras activity was shown to be necessary for the normal time course of induction by NGF, implicating the Ras pathway as an essential component of normal transin induction. Thus, although our data suggest that Src, Ras, and Raf mediate NGF induction of the genes described above, we cannot rule out the possibility that other pathways elicited from the NGF receptor, in addition to the proto-oncogene cascade, also contribute to these effects.

We have not investigated the specific mechanisms by which Src, Ras, and Raf might regulate gene expression. For the genes analyzed in this study, with the exception of the sodium channel genes, it has been reported that the NGFinduced expression is for the most part due to an increase in the rate of transcription $(5,11,34,44,51)$. The ability of p $21^{\mathrm{N} 17}$ to inhibit the induction of these genes by NGF suggests that p21 c-Ras is involved in transcriptional regulation; however, other mechanisms have not been ruled out. The mechanism of sodium channel gene induction has not yet been determined. Promoter sequences responsive to NGF are present in many of the genes that we have examined in this study $(5,34,41,44)$. However, specific NGF-inducible elements are only beginning to be defined (see, for example, reference 20). The role of DNA elements in mediating induction of these genes by growth factors or oncoproteins is currently under investigation. Identification of the DNA-binding proteins involved will be of great interest for understanding the mechanisms of NGF action. It is also worth noting that epidermal growth factor stimulates mitogenesis and not differentiation of $\mathrm{PC} 12$ cells and stimulates expression of only a subset of the NGF- and oncogeneinduced genes, although epidermal growth factor does stimulate at least Ras and Raf activities in these cells $(19,26)$. The apparent paradox presented by these observations has been discussed $(6,26)$ although not resolved. An understand- ing of the mechanisms of gene induction may provide a means for elucidating this question.

An important general implication of our findings is the suggestion that diversity in NGF actions could be achieved by parallel processing through branchpoints in a linear signal transduction cascade. The most impressive example may be provided by the NGF-induced expression of sodium channel genes, which underlies the ability to generate sodium-based action potentials; this effect results from signaling pathways which are distinct from those involved in neurite outgrowth $(9,24,30,45$; this study). Likewise, we have shown that the expression of a specific neuronal marker, exemplified by SCG10, can be uncoupled from neurite growth, from sodium channel-based action potentials, from the expression of other neuronal markers such as VGF, from expression of immediate-early genes such as NGFI-A, and from expression of differentiation-associated genes such as Thy-1 and transin. It will be of interest to determine the extent to which diverse neuronal phenotypic characteristics can be differentially regulated through various elements in the NGF signal transduction pathway in different NGF-responsive neurons. This approach may also provide a means for the differential manipulation of neuronal phenotypic characteristics in vivo.

\section{ACKNOWLEDGMENTS}

We thank M. Corbley, A. Levi, J. Milbrandt, L. M. Matrisian, D. J. Anderson, and G. A. Evans for gifts of plasmids; L. Feig and K. Wood for providing the $17 \mathrm{~N}-2$ and IC4-raf cell lines; and G. Mandel, K. Keegan, J. Brugge, T. Roberts, and M. Evinger for valuable discussions.

This work was supported by grant NS 18218 from the National Institutes of Health (S.H.) and a predoctoral fellowship from Hoffmann-La Roche (G.D.).

\section{REFERENCES}

1. Alemà, S., P. Casalbore, E. Agostini, and F. Tatò. 1985. Differentiation of PC12 phaeochromocytoma cells induced by v-src oncogene. Nature (London) 316:557-559.

2. Bar-Sagi, D., and J. R. Feramisco. 1985. Microinjection of the ras oncogene protein into PC12 cells induces morphological differentiation. Cell 42:841-848.

3. Baybis, M., and S. R. J. Salton. 1992. Nerve growth factor rapidly regulates VGF gene transcription through cycloheximide sensitive and insensitive pathways. FEBS Lett. 308:202206.

4. Cathala, G., G. S. Sabouret, B. Mendez, E. L. West, M. Karin, J. A. Martial, and J. D. Baxter. 1983. Laboratory methods: methods for isolation of intact translationally active ribonucleic acid. DNA 2:329-335.

5. Changelian, P. S., P. Feng, T. King, and J. Milbrandt. 1989. Structure of the NGFI-A gene and detection of upstream sequences responsible for its transcriptional induction by nerve growth factor. Proc. Natl. Acad. Sci. USA 86:377-381.

6. Chao, M. 1992. Growth factors signaling: where is the specificity? Cell 68:995-997.

7. Cooperman, S. S., S. A. Grubman, R. L. Barchi, R. H. Goodman, and G. Mandel. 1987. Modulation of sodium channel mRNA levels in rat skeletal muscle. Proc. Natl. Acad. Sci. USA 84:8721-8725.

8. Danielson, P. E., S. Forss-Petter, M. A. Brau, L. Calavetta, J. Douglass, R. J. Milner, and J. G. Sutcliffe. 1988. pIB15: a cDNA clone of the rat RNA encoding cyclophilin. DNA 7:261-267.

9. D'Arcangelo, G., K. Paradiso, D. Shepherd, P. Brehm, S. Halegoua, and G. Mandel. Unpublished data.

10. Der, C. J., T. Finkel, and G. M. Cooper. 1986. Biological and biochemical properties of human $\operatorname{ras}^{\mathrm{H}}$ genes mutated at codon 61. Cell 44:167-176.

11. Dickson, G., H. Prentice, J. P. Julien, G. Ferrari, A. Leon, and 
F. S. Walsh. 1986. Nerve growth factor activates Thy-1 and neurofilament gene transcription in rat PC12 cells. EMBO J. 5:3449-3453.

12. Farnsworth, C. L., and L. Feig. 1991. Dominant inhibitory mutations in the $\mathrm{Mg}^{2+}$-binding site of $\mathrm{RasH}$ prevent its activation by GTP. Mol. Cell. Biol. 11:4822-4829.

13. Feig, L. A., and G. M. Cooper. 1988. Inhibition of NIH 3T3 cell proliferation by a mutant ras protein with preferential affinity for GDP. Mol. Cell. Biol. 8:3235-3243.

14. Gorman, C., R. Padmanabhan, and B. H. Howard. 1983. High efficiency DNA-mediated transformation of primate cells. Science 221:551-553.

15. Greene, L. A., and A. S. Tischler. 1976. Establishment of a noradrenergic clonal cell line of rat pheochromocytoma cells which respond to nerve growth factor. Proc. Natl. Acad. Sci. USA 73:2424-2428.

16. Greene, L. A., and A. S. Tischler. 1982. PC12 pheochromocytoma cultures in neurobiological research. Adv. Cell. Neurobiol. 3:373-414.

17. Guerrero, I., A. Pellicer, and D. E. Burstein. 1988. Dissociation of c-fos from ODC expression and neuronal differentiation in a PC12 subline transfected with an inducible $\mathrm{N}$-ras oncogene. Biochem. Biophys. Res. Commun. 150:1185-1192.

18. Hagag, N., S. Halegoua, and M. Viola. 1986. Inhibition of growth factor-induced differentiation of $\mathrm{PC} 12$ cells by microinjection of antibodies to ras p21. Nature (London) 319:680-682.

19. Halegoua, S., R. C. Armstrong, and N. E. Kremer. 1991. Dissecting the mode of action of a neuronal growth factor. Curr. Top. Microbiol. Immunol. 165:119-170.

20. Hawley, R. J., R. J. Scheibe, and J. A. Wagner. 1992. NGF induces the expression of the VGF gene through a cAMP response element. J. Neurosci. 12:2573-2581.

21. Hempstead, B. L., D. Martin-Zanca, D. R. Kaplan, L. F. Parada, and M. V. Chao. 1991. High-affinity NGF binding requires coexpression of the trk proto-oncogene and the low-affinity NGF receptor. Nature (London) 350:678-683.

22. Hempstead, B. L., S. J. Rabin, L. Kaplan, S. Reid, L. F. Parada, and D. R. Kaplan. 1992. Overexpression of the Trk tyrosine kinase rapidly accelerates nerve growth factor-induced differentiation. Neuron 9:883-896.

23. Ingraham, H. A., G. M. Lawless, and G. A. Evans. 1986. The mouse Thy-1.2 glycoprotein gene: complete sequence and identification of an unusual promoter. J. Immunol. 136:1482-1489.

24. Kalman, D., B. Wong, A. E. Horvai, M. J. Cline, and P. H. O'Lague. 1990. Nerve growth factor acts through cAMP-dependent protein kinase to increase the number of sodium channels in PC12 cells. Neuron 4:355-366.

25. Kaplan, D. R., D. Martin-Zanca, and L. F. Parada. 1991. Tyrosine phosphorylation and tyrosine kinase activity of the trk proto-oncogene product induced by NGF. Nature (London) 350:158-160.

26. Keegan, K., and S. Halegoua. 1993. Signal transduction pathways in neuronal differentiation. Curr. Opin. Neurobiol. 3:14 19.

27. Kim, U.-H., D. J. Fink, H. S. Kim, D. J. Park, M. L. Contreras, G. Gurofi, and S. G. Rhee. 1991. Nerve growth factor stimulates phosphorylation of phospholipase $\mathrm{C}-\boldsymbol{\gamma}$ in PC12 cells. J. Biol. Chem. 266:1359-1362.

28. Klein, R., S. Jing, V. Nanduri, E. O'Rourke, and M. Barbacid. 1991. The trk proto-oncogene encodes a receptor for nerve growth factor. Cell 65:189-197.

29. Kolch, W., G. Heidecker, P. Lloyd, and U. R. Rapp. 1991. Raf-1 protein kinase is required for growth of induced NIH/3T3 cells. Nature (London) 349:426-428.

30. Kremer, N. E., G. D'Arcangelo, S. M. Thomas, M. DeMarco, J. S. Brugge, and S. Halegoua. 1991. Signal transduction by nerve growth factor and fibroblast growth factor in PC12 cells requires a sequence of src and ras actions. J. Cell Biol. 115:809-819.

31. Levi, A., J. D. Eldridge, and B. M. Paterson. 1980. Molecular cloning of a gene sequence regulated by nerve growth factor. Science 229:3469-3473.

32. Levi-Montalcini, R. 1987. The nerve growth factor 35 years later. Science 237:1154-1162.

33. Lindsay, R. M., and A. J. Harmar. 1989. Nerve growth factor regulates expression of neuropeptides genes in adult sensory neurons. Nature (London) 337:362-364.

34. Machida, C. M., K. D. Rodland, L. Matrisian, B. E. Magun, and G. Ciment. 1989. NGF induction of the gene encoding the protease transin accompanies neuronal differentiation in PC12 cells. Neuron 2:1587-1596.

35. Maher, P. 1988. Nerve growth factor induces protein-tyrosine phosphorylation. Proc. Natl. Acad. Sci. USA 85:6788-6791.

36. Mandel, G., S. S. Cooperman, R. A. Maue, R. H. Goodman, and P. Brehm. 1988. Selective induction of brain type II $\mathrm{Na}+$ channels by nerve growth factor. Proc. Natl. Acad. Sci. USA 85:924-928.

37. Martins, V. R., and M. M. Brentani. 1990. The effects of ras gene expression on glucocorticoid receptors in mouse fibroblasts. J. Steroid Biochem. Mol. Biol. 37:183-193.

38. Matrisian, L. M., N. Glaichenhaus, M. Gesnel, and R. Breathnach. 1985. Epidermal growth factor and oncogenes induce transcription of the same cellular mRNA in rat fibroblasts. EMBO J. 4:1435-1440.

39. Milbrandt, J. 1987. A nerve growth factor-induced gene en codes a possible transcriptional regulatory factor. Science 238 : 797-799.

40. Mobley, W. C., A. Schenker, and E. M. Shooter. 1976. Characterization and isolation of proteolytically modified nerve growth factor. Biochemistry 15:5543-5552.

41. Mori, N., R. Stein, O. Sigmund, and D. J. Anderson. 1990. A cell type-preferred silencer element that controls the neural-specific expression of the SCG10 gene. Neuron 4:583-594.

42. Noda, M., M. Ko, A. Ogura, D. G. Liu, T. Amano, T. Takano, and Y. Ikawa. 1985. Sarcoma viruses carrying ras oncogenes induce differentiation-associated properties in a neuronal cell line. Nature (London) 318:73-75.

43. Oshima, M., G. Sithanandam, U. R. Rapp, and G. Guroff. 1991. The phosphorylation and activation of B-raf in PC12 cells stimulated by nerve growth factor. J. Biol. Chem. 266:2375323760.

44. Possenti, R., G. Di Rocco, S. Nasi, and A. Levi. 1992. Regulatory elements in the promoter region of vgf, a nerve growth factorinducible gene. Proc. Natl. Acad. Sci. USA 89:3815-3819.

45. Rausch, D. M., G. Dickens, S. Doll, K. Fujita, S. Koizumi, B. B. Rudkin, M. Tocco, L. E. Eiden, and G. Guroff. 1989. Differentiation of PC12 cells with v-src: comparison with nerve growth factor. J. Neurosci. Res. 24:49-58.

46. Ritter, A. M., G. R. Lewin, N. E. Kremer, and L. M. Mendell. 1991. Requirement for nerve growth factor in the development of myelinated nociceptors in vivo. Nature (London) 350:500 502.

47. Robbins, D. J., M. Cheng, E. Zhen, C. A. Vanderbilt, L. Feig, and M. Cobb. 1992. Evidence for a Ras-dependent extracellular signal-regulated protein kinase (ERK) cascade. Proc. Natl. Acad. Sci. USA 89:6924-6928.

48. Salton, S. R. J., D. J. Fischberg, and K. W. Dong. 1991. Structure of the gene encoding VGF, a nervous system-specific mRNA that is rapidly and selectively induced by nerve growth factor in PC12 cells. Mol. Cell. Biol. 11:2335-2349.

49. Smith, M. R., S. J. DeGudicibus, and D. W. Stacey. 1986. Requirement for c-ras proteins during viral oncogene transformation. Nature (London) 320:540-543.

50. Soltofi, S. P., S. L. Rabin, L. C. Cantley, and D. R. Kaplan. 1992. Nerve growth factor promotes the activation of phosphatidylinositol 3-kinase and its association with the trk tyrosine kinase. J. Biol. Chem. 267:17472-17477.

51. Stein, R., S. Orit, and D. J. Anderson. 1988. The induction of a neural-specific gene, SCG10, by nerve growth factor in PC12 cells is transcriptional, protein synthesis dependent and glucocorticoid inhibitable. Dev. Biol. 127:316-325.

52. Sugimoto, Y., M. Noda, H. Kitayama, and Y. Ikawa. 1988. Possible involvement of two signalling pathways in induction of neuron-associated properties by v-Ha-ras gene in PC12 cells. J. Biol. Chem. 263:12102-12108.

53. Szeberenyi, J., H. Cai, and G. M. Cooper. 1990. Effect of a 
dominant inhibitory Ha-ras mutation on neuronal differentiation of PC12 cells. Mol. Cell. Biol. 10:5324-5332.

54. Thoenen, H., and Y. A. Barde. 1980. Physiology of nerve growth factor. Physiol. Rev. 60:1284-1335.

55. Thomas, S. M., M. DeMarco, G. D'Arcangelo, S. Halegoua, and J. Brugge. 1992. Ras is essential for nerve growth factor- and phorbol ester-induced tyrosine phosphorylation of MAP kinases. Cell 68:1031-1040.

56. Thomas, S. M., M. Hayes, G. D'Arcangelo, R. C. Armstrong, B. E. Meyer, A. Zilberstein, J. S. Brugge, and S. Halegoua. 1991. Induction of neurite outgrowth by v-src mimics critical aspects of nerve growth factor-induced differentiation. Mol. Cell. Biol. 11:4739-4750.

57. Vetter, M. L., D. Martin-Zanca, L. F. Parada, J. M. Bishop, and
D. R. Kaplan. 1991. Nerve growth factor rapidly stimulates tyrosine phosphorylation of phospholipase $\mathrm{C}-\gamma \mathbf{l}$ by a kinase activity associated with the product of the trk protooncogene. Proc. Natl. Acad. Sci. USA 88:5650-5654.

58. Wood, K. W., H. Qi, G. D'Arcangelo, R. C. Armstrong, T. M. Roberts, and S. Halegoua. Proc. Natl. Acad. Sci. USA, in press.

59. Wood, K. W., C. Sarnecki, T. M. Roberts, and J. Blenis. 1992. ras mediates nerve growth factor receptor modulation of three signal transduction protein kinases: MAP kinase, Raf-1 and RSK. Cell 68:1041-1050.

60. Wright, E. M., K. S. Vogel, and A. M. Davies. 1992. Neurotrophic factors promote the maturation of developing sensory neurons before they become dependent on these factors for survival. Neuron 9:139-150. 